\title{
Oribatid mites from deep soils of Hòn Chông limestone hills, Vietnam: the family Lohmanniidae (Acari: Oribatida), with the descriptions of Bedos/ohmannia anneae n. gen., n. sp., and Paulianacarus vietnamese n. sp.
}

\author{
Nestor FERNANDEZ \\ National Council of Scientific and Technological Research (CONICET), \\ Subtropical Biological Institut (IBS), \\ Evolutive Genetic Laboratory FCEQyN, Misiones National University, \\ Felix de Azara 1552, 3300 Posadas Misiones (Argentina) \\ nestorfernand51@yahoo.fr \\ Pieter THERON \\ Research Unit for Environmental Sciences and Management, \\ North-West University, \\ 2520 Potchefstroom Campus (South Africa) \\ pieter.theron@nwu.ac.za \\ Christine ROLLARD \\ Muséum national d'Histoire naturelle, \\ Département Systématique et Évolution, UMR 7205 \\ case postale 53, 57 rue Cuvier F-75231 Paris cedex 05 (France) \\ chroll@mnhn.fr \\ Elio Rodrigo CASTILLO \\ National Council of Scientific and Technological Research (CONICET), \\ Subtropical Biological Institut (IBS), \\ Evolutive Genetic Laboratory FCEQyN, Misiones National University, \\ Felix de Azara 1552, 3300 Posadas Misiones (Argentina) \\ castillo.eliorodrigo@gmail.com
}

KEY WORDS

Acari,

Oribatida,

Lohmanniidae,

Vietnam,

new genus, new species.
Fernandez N., Theron P., Rollard C. \& Castillo E. R. 2014. - Oribatid mites from deep soils of Hòn Chông limestone hills, Vietnam: the family Lohmanniidae (Acari: Oribatida), with the descriptions of Bedos/ohmannia anneae n. gen., n. sp., and Paulianacarus vietnamese n. sp. Zoosystema 36 (4): 771-787. http://dx.doi.org/10.5252/z2014n4a5

\section{ABSTRACT}

In this first work on the oribatid mite fauna of Hòn Chông limestone hills, Vietnam, we describe Bedoslohmannia anneae n. gen., n. sp. and Paulianacarus vietnamese $\mathrm{n}$. sp., in both cases studied with optical microscopy. Bedoslohmannia n. gen. presents a very interesting "leg-folding process", unusually shaped legs and significant notogastral neotrichy. Paulianacarus Balogh, 1960 is newly reported from Vietnam and $P$. vietnamese $\mathrm{n}$. $\mathrm{sp}$. is most similar to $P$. rugulosus Mahunka, 1995 from Thailand. 


\section{MOTS CLÉS \\ Acariens \\ Oribates \\ Lohmanniidae \\ Vietnam \\ genres nouveaux, \\ espèces nouvelles.}

\begin{abstract}
RÉSUMÉ
Les acariens Oribates des sols profonds des collines calcaires de Hòn Chông, Vietnam: la famille des Lohmanniidae (Acari: Oribatida), avec la description de Bedoslohmannia anneae $n$. gen., n. sp., et Paulianacarus vietnamese n. sp.

Dans ce premier travail sur la faune Oribatologique des collines calcaires de Hòn Chông du Vietnam, nous décrivons Bedoslohmannia anneae n. gen, n. sp. et Paulianacarus vietnamese n. sp., tous deux étudiés en microscopie optique. Bedoslohmannia $\mathrm{n}$. gen. présente un système très intéressant pour replier ses pattes, une forme de pattes très particulière ainsi qu'une importante néotrichie notogastral. Paulianacarus Balogh, 1960 est nouveau pour le Vietnam et $P$. vietnamese $\mathrm{n}$. sp. ressemble à $P$. rugulosus Mahunka, 1995 de Thaïlande.
\end{abstract}

\section{INTRODUCTION}

The Hòn Chông limestone hills of Kien Giang Province, located in the extreme southwestern part of Vietnam, harbours cave and soil invertebrate communities exceptional in richness and micro-endemics (Deharveng et al. 2009). These tiny hills (the largest one has an area of less than one $\mathrm{km}^{2}$ ) are currently under intense pressure due to quarrying, and a large part of their fauna is critically threatened, with high risk of species extinctions. In spite of the large number of genera and species described from this area during the last two decades, plenty of remarkable taxa are yet to be described. The most diversified soil mites, principally oribatids, are also the least studied. A single species of mite (Actinotrichida, Eutrombidiidae) has been described so far from the area (Makol \& Gabrys 2005) and another has been identified (Deharveng et al. 2009), whereas hundreds of species remain to be examined in the samples at hand.

Studying the biodiversity of Hòn Chông limestone hills is a very important consideration in the impact assessment of this small and fragile ecosystem.

The extreme isolation of these karst hills can generate endemism among arthropods (Deharveng et al. 2009) as in other isolated karsts of tropical regions.
"The number of arthropod species collected in Hòn Chông is approaching 500, most of them undescribed. Actually, this number strongly underestimates the total biodiversity of the area, because data resolution is extremely uneven from one group to the other, ranging from species or morphospecies (Collembola, Pauropoda, cave groups...) the family (many millipedes and centipedes) or even order (many spiders, mites, aquatic fauna). Mites in particular have hardly been studied though they would certainly provide the largest diversity of all soil arthropods" (Deharveng et al. 2009: 37).

Bedoslohmannia anneae n. gen., n. sp., described in the present paper displays a very particular type of setae covering the body and legs. At the moment of deployment of the "protection mechanism" (Fernandez et al. 2013a), the legs are concealed behind the large umbrella-shaped setae present on all legs. The notogaster, ventral region and legs also show interesting particularities.

In Paulianacarus vietnamese n. sp., all setae are small and the anal and adanal plates are similar to those in Paulianacarus rugulosus Mahunka, 1995 from Thailand.

Due to the limited number of specimens, their rarity and particularities, we did not perform Scanning Electron Microscopy studies, which would result in the loss of the coated material, thus depositing the largest possible number of specimens in the MNHN. 


\section{MATERIAL AND METHODS}

The material was obtained by Louis Deharveng and Anne Bedos using Berlese-funnel extractors (see particulars under each species) in 2003. Specimens were macerated in lactic acid, and observed in the same medium using the open-mount technique (cavity slide and cover slip) described by Grandjean (1949) and Krantz \& Walter (2009). Drawings were made by means of an Olympus BHC compound microscope (Rungis, France), equipped with a drawing tube.

Measurements taken: total length (tip of rostrum to posterior edge of notogaster) and width (widest part of notogaster), in micrometres $(\mu \mathrm{m})$. Setal formulae of the legs include the number of solenidia (in parentheses); tarsal setal formulae include the famulus $(\varepsilon)$. In order to study several structures, principally notogaster, subcapitulum and legs, and particular setae, specimens were dissected and monitored during the lactic acid maceration process (in warm $70 \%$ lactic acid), before being stained with chlorazol black E (Coineau 1974).

\section{ABBREVIATIONS}

\section{Morphology}

Morphological terms and abbreviations used are those developed by Grandjean (1950); Norton \& Behan-Pelletier (2009); Fernandez et al. (2013a-c).

\section{Institutions}

MNHN Muséum national d'Histoire naturelle, Paris.

\section{SYSTEMATICS}

Family LOHMANNIIDAE Berlese, 1916

Genus Bedoslohmannia n. gen.

TYPE SPECIES. - Bedoslohmannia anneae n. sp.

ETymology. - The generic prefix "Bedos" and the specific epithet are in homage to Dr Anne Bedos, MNHN.

DiAGNOSIS (ADULT)

Notogastral neotrichy

Genital plate undivided, ten pairs of setae; anal and adanal plate fused, with six pairs of setae, four pairs antiaxial and two pairs paraxial situated in the middle posterior zone; preanal plate broadly triangular, posterior part covering the anterior anal-adanal plate zone; preanal plate, anterior part fused on posterior genital opening margin. Leg ventral blades: femora I and II with two prominences; femora III and IV with teeth; all femora presenting umbrella-shaped setae that conceal legs during folding process.

\section{Bedoslohmannia anneae n. sp.}

(Figs 1-4; Table 1)

Type Material. - Holotype: Vietnam, Kien Giang Province; Kien Luong; Nui Hon Chong "sommet est, flanc nord”, 27.I.2003, secondary forest, 1 \%, Berlese funnel extraction of deep mineral soil. Louis Deharveng and Anne Bedos leg. (VIET-929) X 104.647086; Y 10.140744 , alt. 120 m. Paratypes: same data, 2 $ᄋ$. MNHN, preserved in $70 \%$ ethanol.

\section{DiaGNOSIS (ADULT FEMALE) \\ Setation}

Umbrella-shaped and simple. Umbrella-shaped: with two variations, one with rounded and more or less smooth edge, the other with spiky edge. Smooth edge: ro, le, exa, exp; notogastral, subcapitular h, $\mathrm{m}_{2}$; epimeric; genital antiaxial; adanal; spiky edge: in setae. Simple setae: subcapitular a, $\mathrm{m}_{1}$; paraxial genital; paraxial adanal. Umbrella-shaped setae covering almost entire body and legs.

\section{Prodorsum}

Triangular to polyhedral in dorsal view, anteriorly truncated in lateral view; postbothridial transverse band sb, poorly developed. Rostrum rounded; bothridium large, dorso-laterally opened; sensillus setiform, particularly curved, short barbs placed distally; in inserted between bothridia; Notogaster. Transverse bands not observed; setae 31-35 pairs: twelve pairs primary; 21-23 pairs additional neotrichial setae; all umbrella-shaped; $c_{1}, c_{2}, c_{3}$, $d_{1}, d_{2}, c p, e_{1}, e_{2}, f_{1}, f_{2}, h_{1}, h_{2}$ large; neotrichal setae small. Five pairs of lyrifissures present, ia, ip, below unsclerotized lateral longitudinal line; ips on adanal fold band; im above $\mathrm{e}_{2}$ setae and ih posterior to $\mathrm{h}_{2}$ setae. 


\section{Ventral region}

Subcapitular setae, four pairs. Adoral setae: or $_{1}$ largest, with apical bead; or 2 elongate; or $_{3}$ small, sharply tipped. Chelicera: fixed digit, four teeth; chb seta well developed, cha seta only represented by insertion. Apodemata short, clearly visible; epimeric setal formulae 3-1-3-4. Anal setae two pairs; adanal setae four pairs.

\section{Lateral region}

Pedofossa housing retracted legs I-IV clearly visible; unsclerotized longitudinal line, terminating at level of ih lyrifissure.

\section{Legs}

All claws monodactyle, with tooth antiaxially. Femur I, II with three umbrella-shaped setae; III, IV, with one only. Setal formulae I (0-4-3-4-17-1) (2-1-2); II (0-5-3-4-14-1) (1-1-2); III (2-4-2-3-121) $(0-1-1)$; IV (2-3-2-2-12-1) (1-0-0). Solenidia setiform; d setae present on tibia and genu I, II, III and only on genu IV.

\section{DESCRIPTION}

\section{Measurements}

$530 \mu \mathrm{m}(541-519) \times 243 \mu \mathrm{m}(260-230)$ (Holotype $1 \%$ and $2 \circ \%$ paratypes measured).

\section{Shape}

Oval (Fig. 1A, B).

\section{Colour}

Specimens without setae: yellow to light brown; slightly shiny, when observed in reflected light.

\section{Cerotegument}

Almost nonexistent; only small amount present near insertion on first and second legs.

\section{Integument}

Polyhedral microsculpture on prodorsum, zone around bo, only visible in transmitted light.

\section{Setation (legs not included; see Legs and Folding process)}

Two types: umbrella-shaped and simple setae.
Two variants of umbrella shape: one with rounded and more or less smooth edge, the second with spiky edge. Smooth-edged variant found on: prodorsum (Fig. 1B, ro, le, exa, exp setae); notogaster (Fig. 1B, all setae); subcapitular (Fig. 2E, h, $\mathrm{m}_{2}$ ); epimeric (Fig. 2B, all setae); genita (Fig. 2D, (antiaxial setae); adanal setae (Fig. 2D). Spiky-edged variant: only in setae (Fig. 1B).

Simple setae on: subcapitulum, a, $\mathrm{m}_{1}$ (Fig. 2E); paraxial zone of genital plate (Fig. 2D); paraxial setae adanal plate (Fig. 2D).

Umbrella-shaped setae presenting central zone with pedicel; upper part umbrella-shaped, with irregular margin and protuberances of different size and nerves (Figs 1B; 2B, D, E).

\section{Prodorsum}

Triangular to polyhedral in dorsal view (Fig. 1D); triangular, but anteriorly truncated in lateral view (Fig. 2A). Rostrum broadly rounded; chitinous ridge present on either side of prodorsal area (Fig. 1D). Each ro seta inserted near the anterior edge of this ridge; le setae placed near ridge, short distance posteriorly and paraxially to ro; bo large, dorsolaterally opened; si setiform, particularly curved (Figs 1A, B, D; 2A) with a few short barbs; in inserted between bothridia; exa situated near chitinous ridge. Umbrella-shaped setae covering almost entire prodorsum (Fig. 1B); shape difference between in and other prodorsal setae is notable (Fig. 1B).

Faint polygonate pattern present anterior and posterior bo. Postbothridial transverse band $s b$ hardly discernible, only visible in specimens without setae (Fig. 1D). Dorsal view, due transparency (l.d) observed between exa and le (Fig. 1D).

\section{Notogaster}

Transverse bands not observed. Twelve pairs of primary notogastral setae: $c_{1}, c_{2}, c_{3}, d_{1}, d_{2}, c p, e_{1}$, $\mathrm{e}_{2}, \mathrm{f}_{1}, \mathrm{f}_{2}, \mathrm{~h}_{1}$ and $\mathrm{h}_{2}$ well discernible, and between 21-23 pairs of additional neotrichial setae (Fig. 1C), situated behind $\mathrm{h}_{2}$. Umbrella-shaped setae covering almost entire notogaster (Fig. 1B).

Five pairs of lyrifissures present, ia, ip, situated below the unsclerotized lateral longitudinal line 

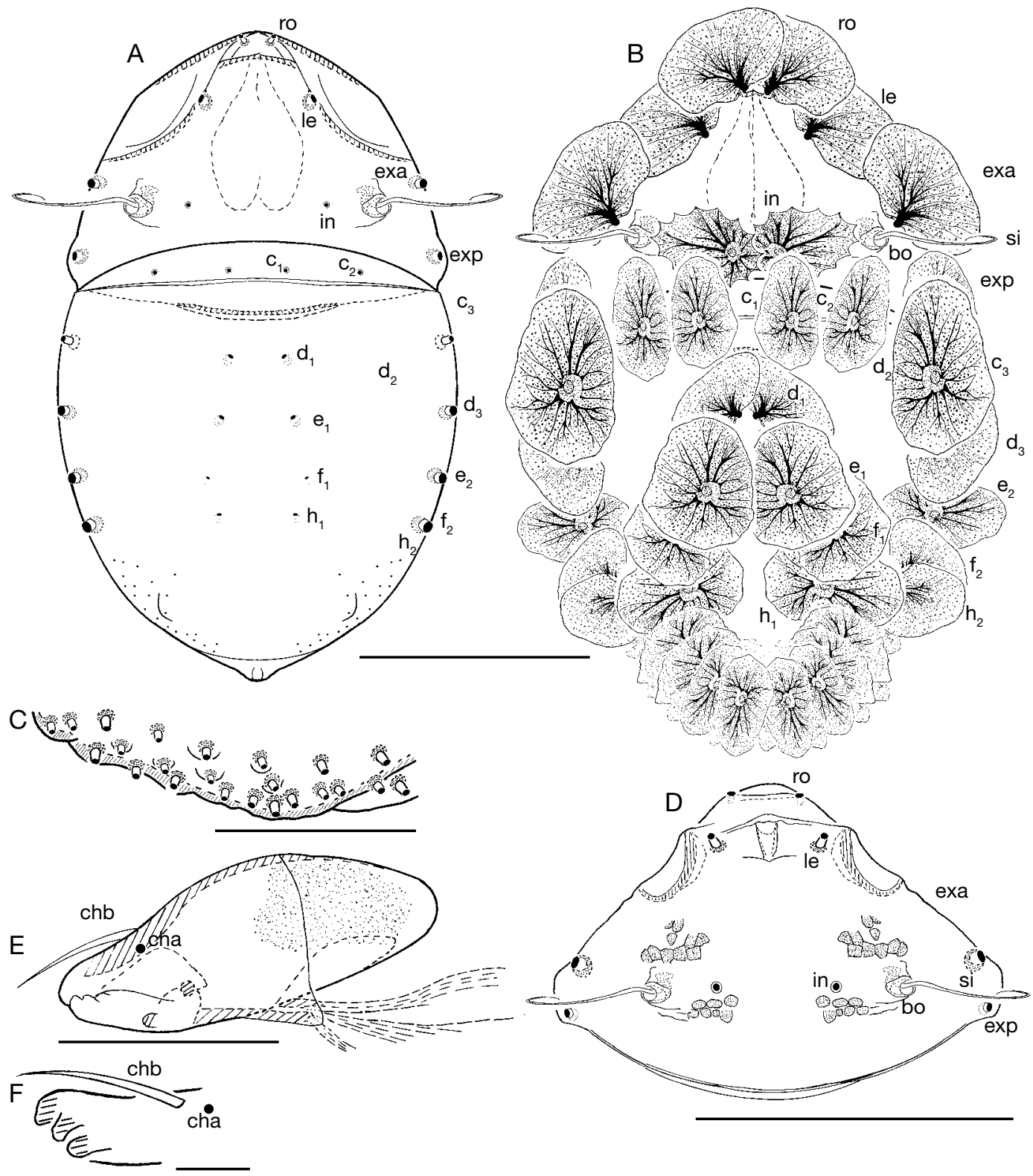

FIG. 1. - Bedoslohmannia anneae n. gen., n. sp. adult: A, dorsal view, without setae; B, dorsal view with setae; C, setal neotrichy disposition; D, prodorsum; E, chelicera; F, fixed digit. Abbreviations: see Material and methods. Scale bars: A, B, $100 \mu \mathrm{m} ; \mathrm{C}, \mathrm{E}, 50 \mu \mathrm{m}$; $\mathrm{D}, \mathrm{F}, 150 \mu \mathrm{m}$.

(Fig. 2A) (see Lateral region); ips situated on the adanal fold band (Fig. 2C [BPAD]); im above $e_{2}$ setae and ih behind $\mathrm{h}_{2}$ (Fig. $2 \mathrm{C}$ ).

\section{Lateral region}

Prodorsal margin present on either side of cavities where legs I and II are housed when retracted; 
TABLE 1. - Bedoslohmannia anneae n. gen., n. sp., setae and solenidia. Abbreviations: see Material and methods.

\begin{tabular}{|c|c|c|c|c|c|}
\hline Leg I & Femur & Genu & Tibia & Tarsus & Claw \\
\hline $\begin{array}{l}\text { Seta } \\
\text { Solenidia }\end{array}$ & va, vp, l”, d & $\begin{array}{l}(\mathrm{l}), \mathrm{d} \\
\sigma_{1}, \sigma_{2}\end{array}$ & $\begin{array}{l}d,(I), v \\
-\varphi-\end{array}$ & $\begin{array}{l}\text { (p), (it), (tc), (ft), } \varepsilon, p^{\prime},(p v), s,(a),(u) \\
---\omega_{1}, \omega_{2}-\end{array}$ & 1 \\
\hline \multicolumn{6}{|l|}{ Leg II } \\
\hline $\begin{array}{l}\text { Seta } \\
\text { Solenidia }\end{array}$ & d, I', va, vp, Ip & $\begin{array}{l}d,(l) \\
-\sigma-\end{array}$ & $\begin{array}{l}d,(I), v \\
-\varphi-\end{array}$ & $\begin{array}{l}\text { (ft), tc', (it), (p), (u), (a), s, (pv) } \\
-\omega_{1}, \omega_{2}-\end{array}$ & 1 \\
\hline \multicolumn{6}{|l|}{ Leg III } \\
\hline $\begin{array}{l}\text { Seta } \\
\text { Solenidia }\end{array}$ & $(\mathrm{l}), \mathrm{lp}, \mathrm{d}$ & $\begin{array}{l}\text { l', d } \\
-\sigma-\end{array}$ & $\begin{array}{l}d, l^{\prime}, v \\
-\varphi^{-}\end{array}$ & $(\mathrm{u}),(\mathrm{p}),(\mathrm{tc}),(\mathrm{ft}), \mathrm{a}^{\prime}, \mathrm{s},(\mathrm{pv})$ & 1 \\
\hline \multicolumn{6}{|l|}{ Leg IV } \\
\hline $\begin{array}{l}\text { Seta } \\
\text { Solenidia }\end{array}$ & Ip, l', la & $\begin{array}{l}\mathrm{d}, \mathrm{l} \\
---\sigma\end{array}$ & $\begin{array}{l}d, \text { l' } \\
-0-\end{array}$ & $(\mathrm{u}),(p),(\mathrm{tc}),(\mathrm{it}), \mathrm{a}^{\prime}, \mathrm{s},(\mathrm{pv})$ & 1 \\
\hline
\end{tabular}

clearly visible prodorsal posterior margin (b.p) and attachment lines of articular skin $\lambda_{1}$ and $\lambda_{2}$ (with prodorsum and notogaster respectively) (Fig. 2A).

Anterior notogastral zones presenting conspicuous tectum (Fig. 2A) and clearly defined unsclerotized lateral longitudinal line, terminating almost at level of ih lyrifissure and delimiting notaspis (unpaired dorsal) and pleuraspis (paired narrow lateral zones) (Fig. 2A); in posterior notogastral zone, when unsclerotized line does not exist, notaspis and pleuraspis not delimited (Fig. 2A).

Anteriorly each pleuraspis presenting a rounded lobe between legs II and III, where lyrifissure ia is present; posteriorly at level of $d_{3}$ and $e_{2}$ setae, well-marked edge forming roof of cavities in which legs III and IV are housed when retracted, with a protruding angle between them (Fig. 2A).

\section{Ventral region}

Subcapitulum anterior zone more or less triangular, posterior zone ovoid. Four pairs of subcapitular setae (Fig. 2E) (see Setation). Adoral setae characteristic: or $_{1}$ largest, with apical bead; or ${ }_{2}$ elongate; or $_{3}$ with small sharp tip (Fig. 2F). Chelicera fixed digit with four teeth, one of them paraxial (indicated in Fig. 1F with dotted shading); chb setae well developed; only insertion of cha setae visible, situated laterally and posterior to chb (Fig. 1E).

Coxisternal region divided into two parts by the ventrosejugal groove. Apodemes short and clearly visible; epimeric setal formulae 3-1-3-4, all seta of similar shape (Fig. 2B) (See Setation). Genital plate undivided with ten pairs of setae (Fig. 2D); six simple setae aligned paraxially, four umbrellashaped setae antiaxially in semi-circle, following shape of genital plate margin. Preanal plate more or less triangular: anterior margin fused to posterior margin of genital opening, impossible to remove without breaking (Fig. 2C); posterior margin covering anterior part of ano-adanal plate, internally excavated to receive them (Fig. 2C).

Anal plate fused to adanal, resulting in single ano-adanal plate with six pairs of setae (Fig. 2C, D). Paraxial alignment of two simple setae situated in the middle posterior zone of the plate; antiaxial alignment with four umbrella-shaped setae (Fig. 2C, D). Band BPAD clearly visible in specimens immersed in lactic acid for a lengthy period; lyrifissure ips present near margin of this band (Fig. 2C, D).

\section{Legs}

Studying the legs is very complex, and due to limited number of adults available for study, it is necessary to consider our study preliminary (see Remarks).

Legs are particular by their shape, principally at femur level (Fig. 3A-D), and due to the presence of the very large umbrella-shaped setae.

Each claw bearing a single prominent tooth situated antiaxially (Fig. 3A-D).

Between tarsus and genu, all legs have a classic appearance, but femora present particular charac- 

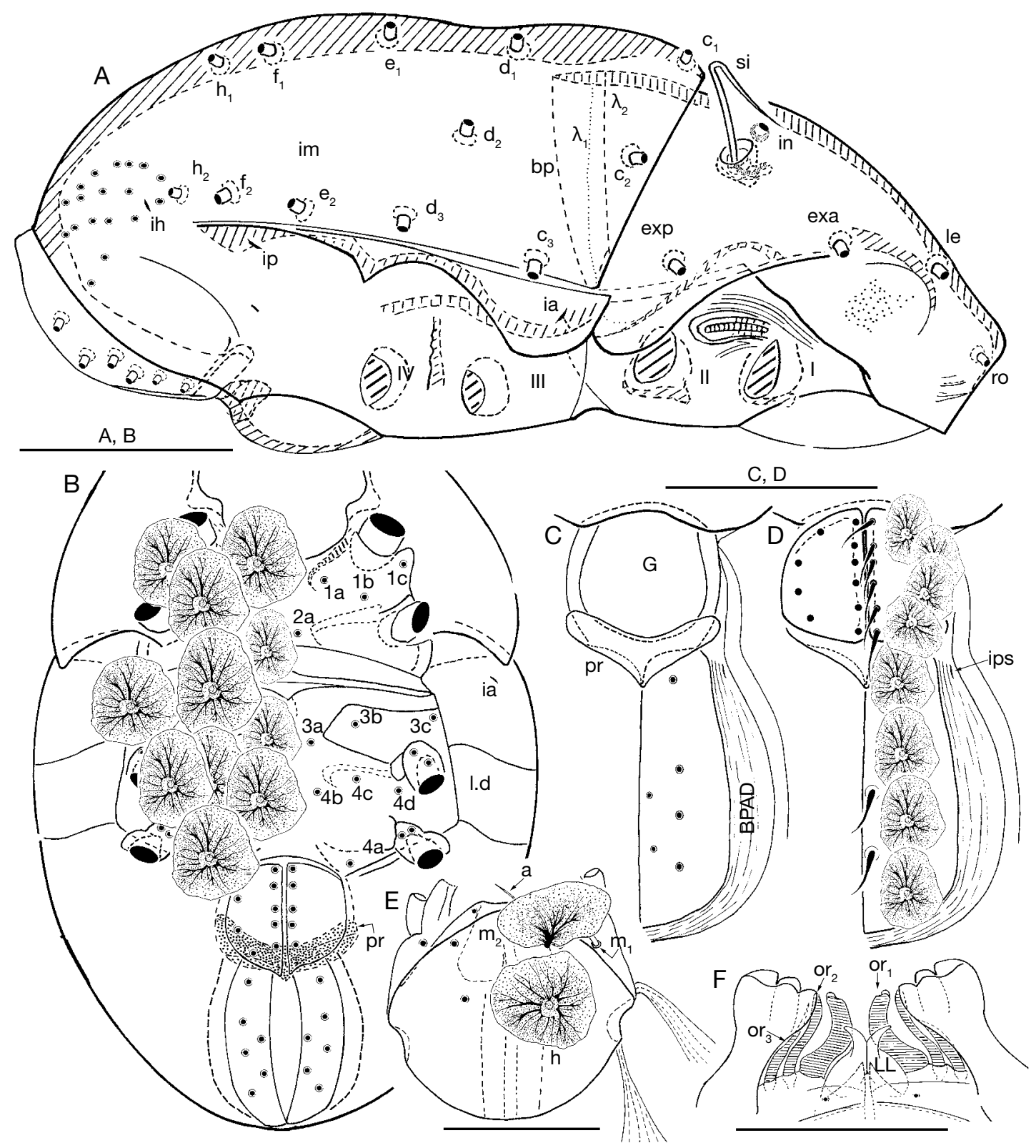

FIG. 2. - Bedoslohmannia anneae n. gen., n. sp. adult: A, lateral view; B, ventral view (genital and ano-adanal zone, semi-schematic); C, genital opening, preanal plate and adanal plate without setae; D, genital opening, preanal plate and adanal plate with setae; E, subcapitulum; F, adoral setae. Abbreviations: see Material and methods. Scale bars: A-D, $100 \mu \mathrm{m} ; \mathrm{E}, 60 \mu \mathrm{m} ; \mathrm{F}, 20 \mu \mathrm{m}$.

teristics. Two types of femur can be distinguished. Femora legs I and II displaying large ventral blade (Fig. 3A, B), with two prominences, carrying three umbrella-shaped setae. Femora legs III and IV has ventral blade, with teeth, carrying only one umbrella-like seta (Fig. 3C, D).

Femur I robust, wide and long; ventral blade situated on proximal part, presenting two more or less 


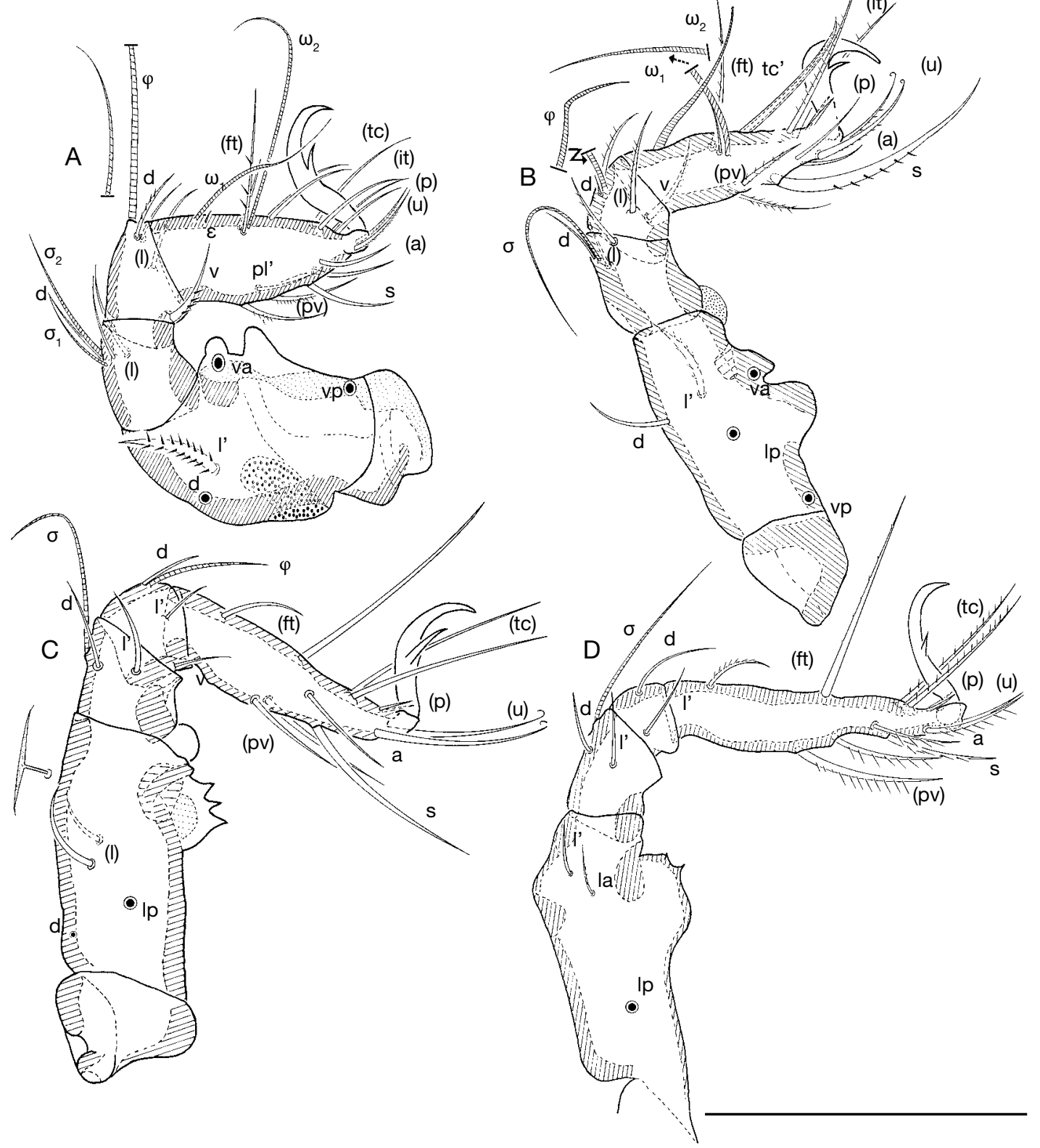

FIG. 3. - Bedos/ohmannia anneae n. gen., n. sp. adult: A, leg I, antiaxial; B, leg II, antiaxial; C, leg III, antiaxial; D, leg IV, antiaxial. Abbreviations: see Material and methods. Scale bar: $70 \mu \mathrm{m}$.

rounded prominences, the distal largest; insertion of one umbrella-shaped seta on distal one. Second umbrella-like seta situated at the same level, but more dorsally, the third towards posterior near articulation with trochanter. Femur II differing in shape; narrower and less robust, ventral blade situ- 


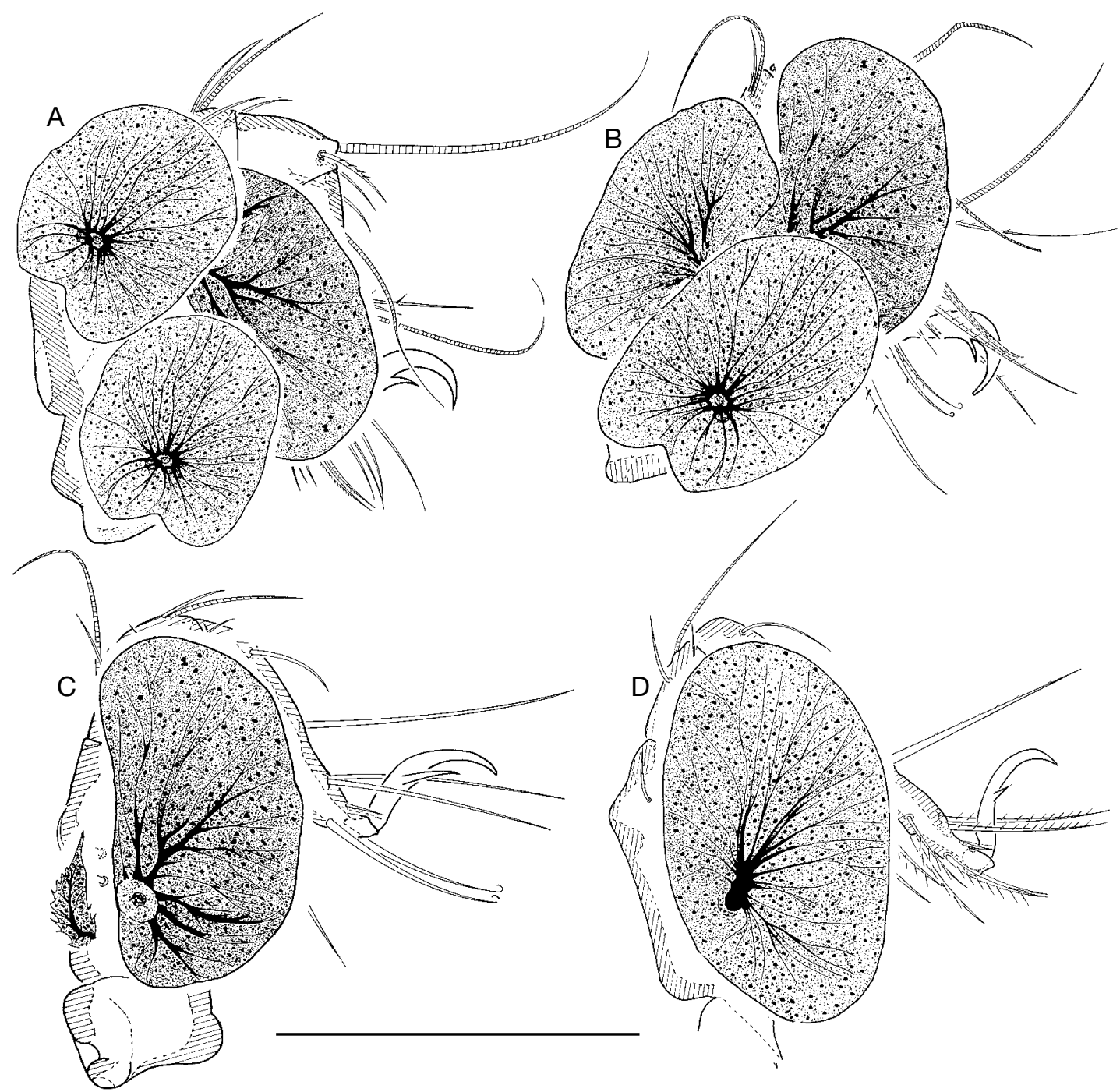

FIG. 4. - Bedos/ohmannia anneae n. gen., n. sp. adult, leg folding: A, leg I; B, leg II; C, leg III; D, leg IV. Scale bar: 70 m.

ated further back than in femur I. Proximal prominences small, polyhedral, and carry insertion of one umbrella-shaped seta; distal prominence rounded and larger than the previous. Second umbrellashaped seta situated distal to first, the third distal near articulation with trochanter.

Femur III presenting ventral blade with three teeth, umbrella-shaped seta situated towards distal; dorsal leaf-shaped setae present, small in relation to umbrella-shaped setae. Femur IV displaying more or less rounded blade with only two teeth; umbrella-shaped setae situated distal.

Setal formulae I (0-4-3-4-17-1) (2-1-2); II (05-3-4-14-1) (1-1-2); III (2-4-2-3-12-1) (0-1-1); IV (2-3-2-2-12-1) (1-0-0).

All solenidia setiform; setae d present on tibia and genu I, II, III and genu IV, situated near solenidia (Fig. 3A-D). 


\section{Leg folding process}

Depressions housing legs (l.d) are depressed zones concave-arc shaped, directing slightly obliquely, situated externally to epimeric zone (indicated by Grandjean 1950). At the moment of leg-folding, this zone partially conceals legs. Evidently the paraxial side is the unique protected zone. In this instance, depressions l.d show a complementary association with umbrella-shaped setae situated on the antiaxal surface of legs and femurs.

During leg-folding, tarsus and tibia are directed towards trochanter and femur, and the genu functions as a hinge (Fig. 4A-D). Legs are housed in depressions and large umbrella-shaped setae cover the entire antiaxial side. This protection mechanism is very simple, but effective. Umbrella-shaped epimeric setae assisting with camouflage, resulting in legs being very difficult to detect in specimens with all setae intact.

In Figure 4A-C, legs are not completely folded, permitting an understanding of positioning of legs. When fully folded, as seen in several cases, only extremities of long setae and the part of solenidia are visible (see Discussion).

\section{REMARKS}

Observation by optical microscopy is difficult due to dorsal and ventral covering of specimens by umbrella-shaped setae, which have to be removed for study.

Legs are challenging to study, because in all specimens legs were situated in leg-housing depressions, and obtaining whole legs by dissection with all setae intact was almost impossible. Preparations containing lactic acid resulted in margins of umbrella-shaped setae becoming torn. Setal shapes were similar in all cases, but sizes varied; in several cases, during observation of setae slightly from the side, they appeared to be fan-shaped structures.

Neotrichous setae are small in relation to others. Determining the number of setae affected by neotrichy necessitated removal of all, and observing insertions. A similar situation arose on the epimeric zone where all setae were removed and insertions studied.

One of the particularities of $B$. anneae n. gen., n. sp. is the "leg-folding process" involving umbrella-shaped setae on femora, and the leg housing depressions situated in the lateroventral zone. Processes observed in Bovicarabodes and Bedoslomannia are very different and involve dissimilar structures and strategies.

Grandjean (1950: 101) indicated that the leg housing depression, "Niches latérales pour les pattes", permits receiving of legs when the specimen retracts them against the body. This observation by Grandjean is very important, but detailed studies on this aspect of Lohmanniidae were not made (Norton 2010 cited in page 9 and 14 this structures with the term "pedofossae", as a characteristic of Lohmanniidae). Our initial observations created the impression that these mites had no legs as none were visible. The problem was that specimens were covered by umbrella-shaped setae and soil particles, together impeding adequate observation. Soil particles were eliminated and legs were found completely concealed behind umbrellashaped setae on legs, and legs retracted in the leg housing depressions. Epimeric umbrella-shaped setae contributed to the protection mechanism.

On legs I and II we found three umbrella-shaped setae and on III and IV only one. In both cases, when legs are retracted to their maximum, only the apical zone of the longest setae and the solenidia are partially visible. Femoral shape and the number of umbrella-shaped setae vary among legs I-IV, possibly related to the larger number of sensorial organs to protect (in an evolutionary sense).

\section{Genus Paulianacarus Balogh, 1960}

\section{Paulianacarus vietnamese $\mathrm{n}$. sp.}

(Figs 5-7; Table 2)

ETymology. - The specific epithet is dedicated to the country Vietnam, where the specimens were collected; vietnamese $($ Latin $=$ to Vietnam).

Type Material. - Holotype: Vietnam, Kien Giang province; Kien Luong; Hon Chong, Nui Hon Chong: "nord-est de la colline, bosquet en bas de pente, terre noire fine assez sèche", 27.I.2003, secondary forest, 1 \%, Berlese extraction: Louis Deharveng and Anne Bedos leg. (VIET-930). X 104.649000; Y 10.139020 alt. 5 m. Paratypes: same data, $2 \%$. MNHN, preserved in $70 \%$ ethanol. 


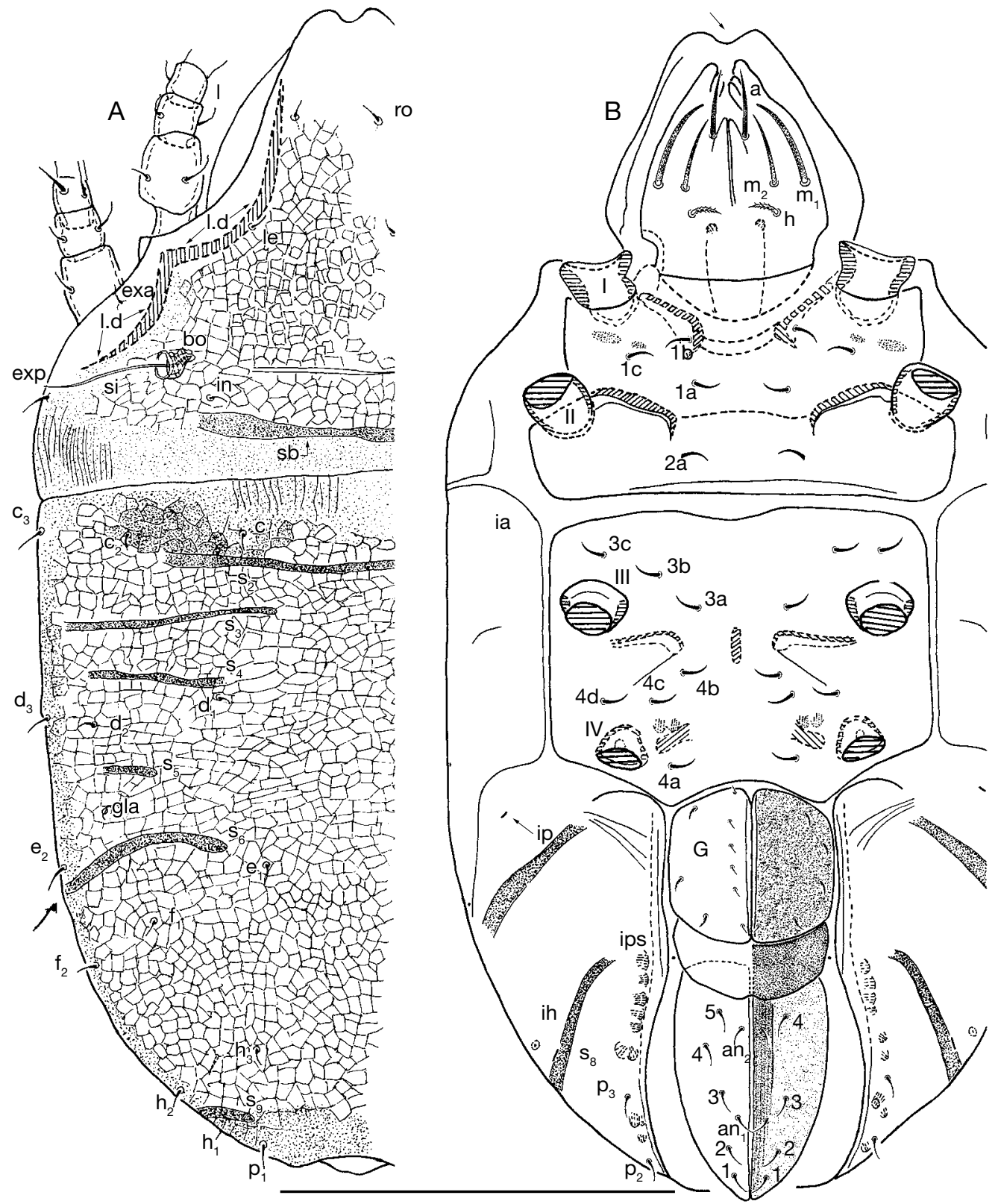

FIG. 5. - Paulianacarus vietnamese n. sp. adult: A, dorsal view; B, ventral view. Abbreviations: see Material and methods. Scale bar: $170 \mu \mathrm{m}$.

DiagNOSIS

Complex microsculpture: punctillate, polyhedral. Three types of setae: simple, small: prodorsum, notogaster, epimeric area, genital paraxially, aggenital, anal, adanal; simple, large, thick: subcapitular $\mathrm{a}, \mathrm{m}_{1}$, $\mathrm{m}_{2}$; barbate: subcapitular h, genital antiaxially. Prodorsum. triangular, polyhedral; rostrum bilobate; ro setae inserted distant from rostrum; le seta posteriorly 
and laterally to ro setal insertion level; bo cup-shaped, dorsally opened; si, setiform, small barbs distally; in setae posterior to bothridium and near transverse band; exa, exp positioned marginally. Postbothridial transverse band sb clearly discernible, posterior to le setae and anterior to dorsosejugal furrow.

\section{Notogaster}

Sixteen pairs of setae: $c_{1}, c_{2}, c_{3}, d_{1}, d_{2}, c p, e_{1}, e_{2}, f_{1}$, $f_{2}, h_{1}, h_{2}, h_{3}, p_{1}, p_{2}, p_{3}$. Transverse band $S_{2}$ situated posterior to c setal alignment, only band crossing sagittal plane; $S_{3}, S_{4}$ between c, d setal alignment; $\mathrm{S}_{5}$ small, behind $\mathrm{d}$ setal alignment; $\mathrm{S}_{6}$ curving, posterior to $e_{2}$ setal insertion; $S_{8}$ visible in ventral view, anterior to $\mathrm{p}_{3} ; S_{9}$ posterior to $h_{2}$. Five pairs of lyrifissures: ia, ih, im, ip, ips.

\section{Lateral region}

Pleuraspis anterior zone rounded lobe; between legs I, II, zone small teeth; unsclerotized longitudinal line exceeding level ih lyrifissure.

\section{Ventral region}

Four pairs of subcapitular setae; epimeric setal formulae 3-1-3-4; genital plate undivided, 10 pairs of setae paraxially, four antiaxially; ano-adanal plate incompletely fused; anterior part of plate, presenting a very faint line, permitting identification of both plates in this zone; six pairs of setae; lyrifissure ips present as rounded structure on adanal fold band.

\section{ADULT DESCRIPTION}

Measurements

$788 \mu \mathrm{m}(815-790) \times 441 \mu \mathrm{m}(448-432)$ (three specimens; deposited in MNHN). All specimens female.

\section{Shape}

Ovoid elongate (Fig. 5A, B).

\section{Colour}

Yellow to light brown; slightly shiny when observed in reflected light.

\section{Cerotegument}

Nonexistent; or disappearing during observation in lactic acid.

\section{Integument}

Complex microsculpture; punctillate cuticular surface and a little below polyhedral (Fig. 7D), microsculpture very difficult to observe on cuticular structures for example transverse band.

\section{Setation (legs not included)}

Three types: a) simple, small: prodorsum, notogaster, epimeric, genital paraxially, aggenital, anal, adanal, (Figs 5A, B; 6A); b) simple, large, thick: subcapitular a, $\mathrm{m}_{1}, \mathrm{~m}_{2}$ (Fig. 5B); c) barbate: subcapitular $\mathrm{h}$, genital antiaxially (Fig. 5B).

\section{Prodorsum}

Triangular to slightly polyhedral in dorsal view (Fig. 5A); triangular in lateral view (Fig. 6A). Rostrum with medial rounded incision, defining a bilobate rostrum (Fig. 6A; indicated by arrow), only visible in dorsal or ventral views (Figs $5 \mathrm{~A}, \mathrm{~B}$ ).

Depression housing legs 1.d (for legs I and II) (Fig. 5A) well visible as concave arc-shaped zones, situated laterally (arrows indicating the course in Fig. 5); ro setae inserted far from rostrum at level of anterior arched margin of l.d (observed by transparency) (Fig. 5A); le setae placed posteriorly and laterally to ro setae insertion level; le setal insertion found at level of more arched zone of l.d (Figs 5A; 6A) (observed by transparency); bo cup-shaped, dorsally opened (Fig. 6C); si setiform, with few small barbs distally (Figs 5A; 6B); in inserted posterior to bothridium and near transverse band sb (Figs 5A; $6 \mathrm{~A})$; exa and exp well visible, situated marginally (Figs 5A; 6A). Transverse postbothridial band sb clearly discernible in dorsal and lateral views; situated posteriorly to le setae and anteriorly to $\mathrm{dsj}$ furrow; lateral end at bothridial level (Figs 5A; 6A).

\section{Notogaster}

Sixteen pairs of notogastral setae: $c_{1}, c_{2}, c_{3}, d_{1}, d_{2}$, cp, $e_{1}, e_{2}, f_{1}, f_{2}, h_{1}, h_{2}, h_{3}, p_{1}, p_{2}, p_{3}$ clearly discernible (Figs 5A; 6A).

Transverse bands: $S_{2}$ clearly visible (Figs 5A; 6A), situated posterior to $\mathrm{c}$ setal alignment, only band crossing sagittal plane; medial limit indistinct and variable among specimens. In dorsal view (Fig. 5A) the limit is between setal insertions $c_{1}$ and $c_{2}$. In lateral view (Fig. 6A) the same limit almost forming 


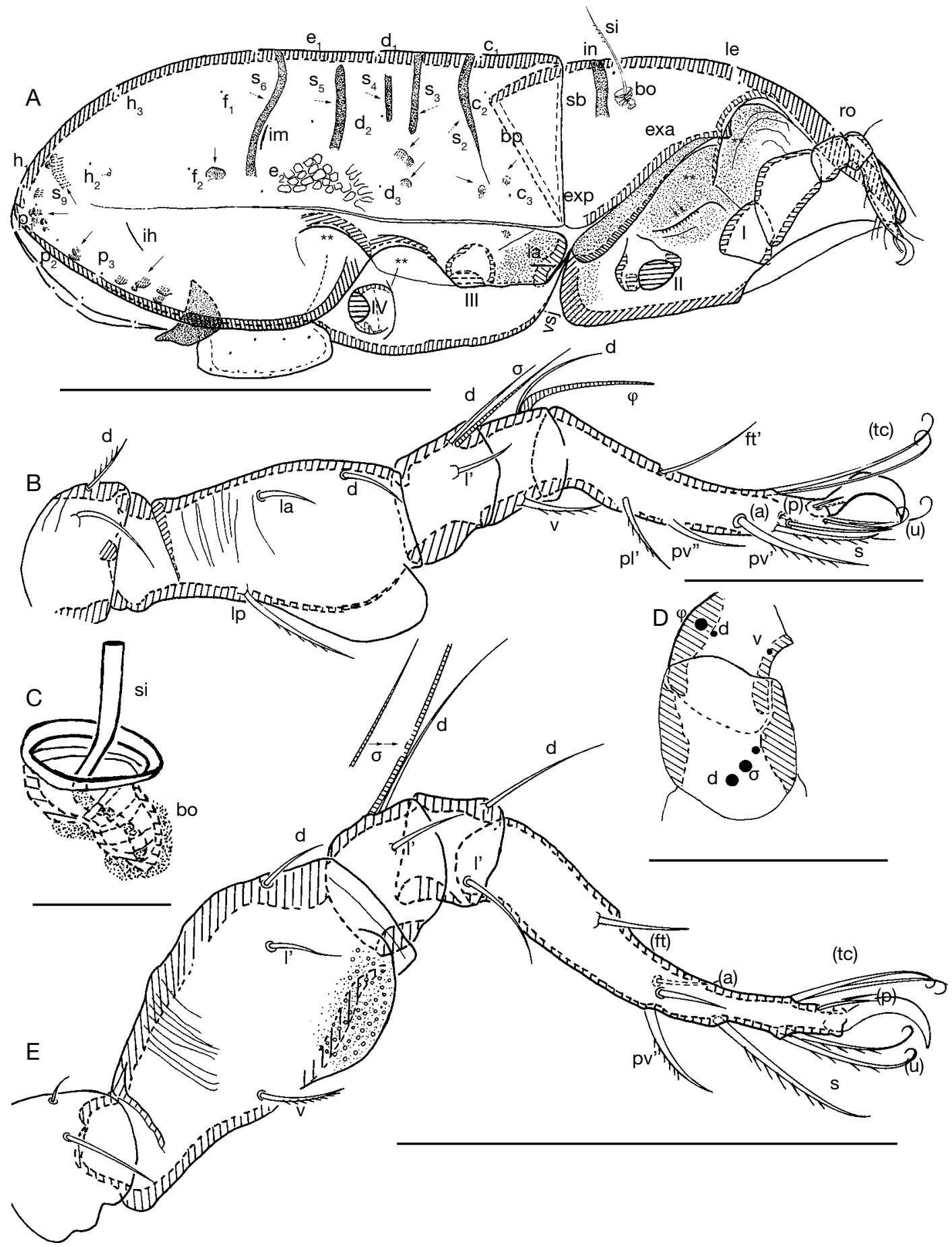

FIG. 6. - Paulianacarus vietnamese n. sp. adult female: A, lateral view; B, leg III antiaxial; C, bothridium, lateral view; D, genu, tibia III, dorsal view; E, leg IV, antiaxial. Abbreviations: see Material and methods. Scale bars: A, $350 \mu \mathrm{m} ; \mathrm{B}, \mathrm{E}, 270 \mu \mathrm{m} ; \mathrm{C}, 23 \mu \mathrm{m} ; \mathrm{D}, 45 \mu \mathrm{m}$. 
TABLE 2. - Paulianacarus vietnamese n. sp., setae and solenidia. Abbreviations: see Material and methods.

\begin{tabular}{|c|c|c|c|c|c|}
\hline Leg I & Femur & Genu & Tibia & Tarsus & Claw \\
\hline $\begin{array}{l}\text { Seta } \\
\text { Solenidia }\end{array}$ & Ip, bv, v, d, l" & $\begin{array}{l}\mathrm{d},(\mathrm{l}) \\
\sigma_{1}, \sigma_{2}\end{array}$ & $\begin{array}{l}(I), x, v \\
-\varphi-\end{array}$ & $\begin{array}{l}\text { (pv), m, n, s, (a), (u), (p), (tc), (ft), } \varepsilon \\
-\omega_{1}, \omega_{2}-\end{array}$ & 1 \\
\hline \multicolumn{6}{|l|}{ Leg II } \\
\hline $\begin{array}{l}\text { Seta } \\
\text { Solenidia }\end{array}$ & $\mathrm{d}, \mathrm{v}, \mathrm{vp}, \mathrm{Ip},(\mathrm{l})$ & $\begin{array}{l}\mathrm{d},(\mathrm{l}) \\
-\sigma-\end{array}$ & $\begin{array}{l}\text { d, (l), } \\
-\varphi^{-}\end{array}$ & $\begin{array}{l}(p v), s,(a),(u),(p),(t c),(f t) \\
\omega\end{array}$ & 1 \\
\hline \multicolumn{6}{|l|}{ Leg III } \\
\hline $\begin{array}{l}\text { Seta } \\
\text { Solenidia }\end{array}$ & $\begin{array}{l}\text { d, l' } \\
--y^{\prime}\end{array}$ & $\begin{array}{l}\text { Ip, la, d } \\
-\sigma-\end{array}$ & $\begin{array}{l}v, d \\
-\varphi-\end{array}$ & $\mathrm{ft}^{\prime}, \mathrm{pl}{ }^{\prime},(\mathrm{pv}), \mathrm{s},(\mathrm{a}),(\mathrm{u}),(\mathrm{tc}),(\mathrm{p})$ & 1 \\
\hline \multicolumn{6}{|l|}{ Leg IV } \\
\hline $\begin{array}{l}\text { Seta } \\
\text { Solenidia }\end{array}$ & d, l', v & $\begin{array}{l}\mathrm{d}, \mathrm{l} \\
---\sigma\end{array}$ & $\begin{array}{l}\mathrm{d}, \mathrm{l}^{\prime} \\
-0-\end{array}$ & $(\mathrm{ft}),(\mathrm{a}), \mathrm{pv},(\mathrm{tc}),(\mathrm{p}),(\mathrm{u}), \mathrm{s}$ & 1 \\
\hline
\end{tabular}

a line terminating near $\mathrm{c}_{3}$ setal insertion; $\mathrm{S}_{3}$ and $\mathrm{S}_{4}$ found between $c$ and $d$ setal alignment (Figs $5 \mathrm{~A} ; 6 \mathrm{~A}$ ); $S_{5}$ small, situated posteriorly to $d$ setal alignment and anteriorly to gla (Fig. 5); $S_{6}$ curving, situated posterior to $e_{2}$ setal insertion; $S_{8}$ only visible in ventral view (Fig. 5B) anteriorly to $\mathrm{p}_{3}$ setal level; $\mathrm{S}_{9}$ situated posteriorly to $h_{2}$ setal level (Figs 5A; 6A).

Five pairs of lyrifissures present: ia, ih, big size, situated below unsclerotized lateral longitudinal line; ia anteriorly on frontal lobe of pleuraspis (see Lateral region); ih situated between $\mathrm{h}_{2}, \mathrm{f}_{2}$ setal level, well visible in lateral and ventral views (Figs 5B; $6 \mathrm{~A}$ ), in ventral view, near $S_{8}$ band, but in variable position situated either in front of or behind this band; im large, situated above unsclerotized lateral longitudinal line, near $\mathrm{S}_{6}$ band, clearly visible in lateral view (Fig. 6A); ip small; visible in ventral view (Fig. 5B); ips rounded, situated on BPAD fold band (Fig. 5B).

\section{Lateral region}

Prodorsal margin presenting depression housing legs l.d, clearly visible (indicated with asterisks Fig. 6A) for legs I, II; bp well visible. Anterior zone of pleuraspis presenting rounded lobe with lyrifissure ia. Laterally between legs I and II, zone with small teeth (Fig. 6A, indicated with double arrow). Anterior notogastral zone presenting conspicuous tectum (Fig. 6A). Unsclerotized longitudinal line easily discernible, exceeding the level of ih lyrifissure and clearly delimiting notaspis and pleuraspis
(Fig. 6A). Situated posteriorly on same pleuraspis, l.d of legs III, IV. Posterior zone (where unsclerotized line does not exist) very small (Fig. 6A). Several muscular insertions visible (Fig. 6 indicated with black arrow).

\section{Ventral region}

Subcapitular setae, four pairs (Fig. 5B, see Setation). Apodemes well visible; epimeric setal formulae 3-13-4. All setae of similar shape (Fig. 2B, see Setation). Genital plate undivided with ten pairs of setae (Fig. 5B); six aligned paraxially and four antiaxially in semi-circle following shape of the genital plate margin. Preanal plate typically shaped, characteristic of the genus (Fig. 5B). Anal plate fused with adanal, delimiting single plate with six pairs of setae (Fig. 5B), anterior part of both plates with faint line, representing vestige of fusion (see Remarks). BPAD clearly visible after lengthy soaking in lactic acid; lyrifissure ips rounded, positioned near band margin (Fig. 5B).

\section{Legs}

Setal formulae I (0-5-3-4-16-1) (2-1-2); II (06-3-3-13-1) (1-1-1); III (2-2-3-2-13-1) (1-1-0); IV (2-3-2-2-12-1) (1-0-0).

\section{REMARKS}

Microsculpture complicating observation: limits of transverse band $S_{2}$ very hard to detect in dorsal view; in lateral view, easier, as this limit almost 


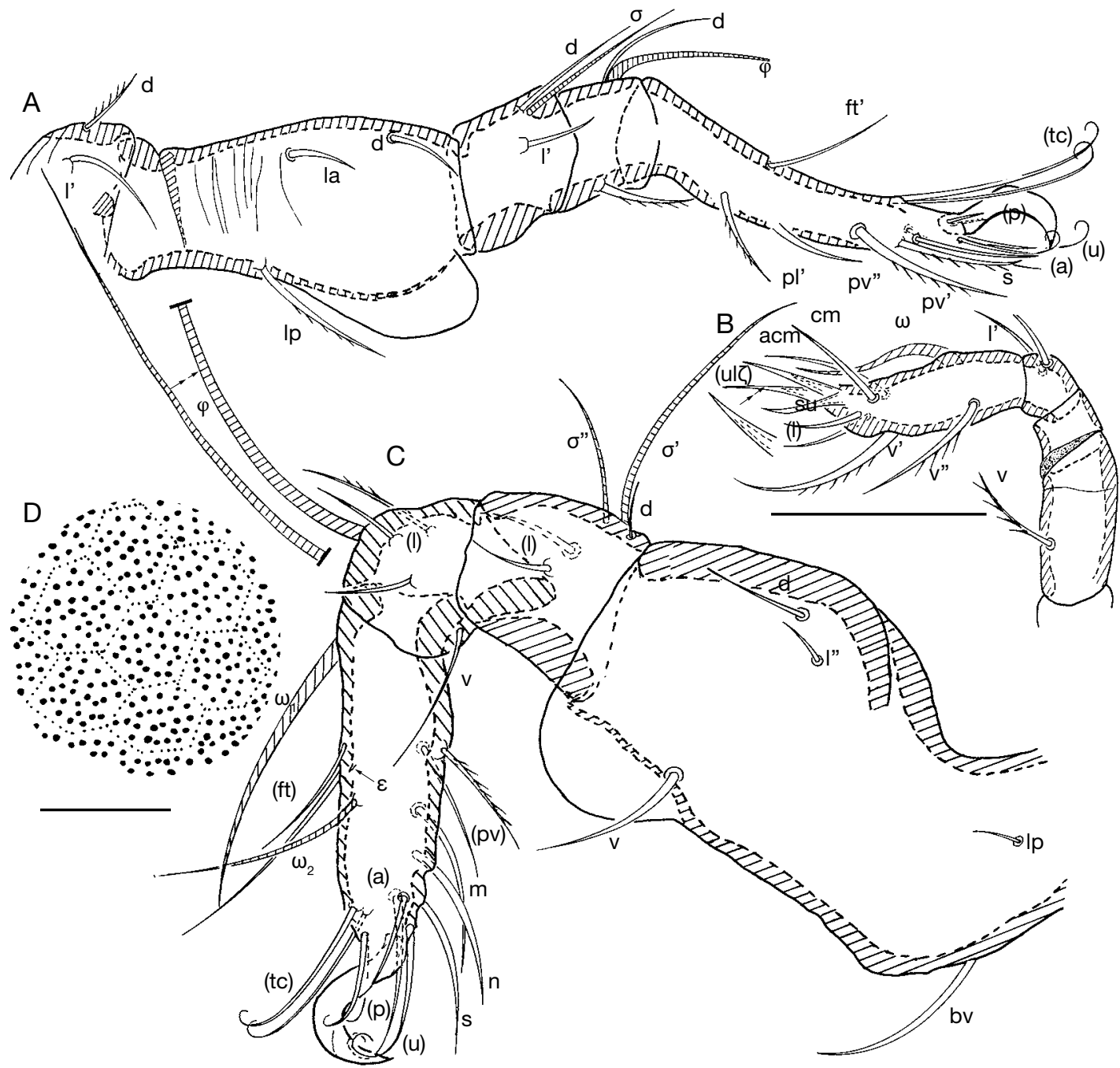

FIG. 7. - Paulianacarus vietnamese n. sp. adult: A, leg I, antiaxial; B, palp, antiaxial; C, leg II, antiaxial; D, microsculpture. Abbreviations: see Material and methods. Scale bars: A, C, $350 \mu \mathrm{m}$; B, $100 \mu \mathrm{m} ; \mathrm{D}, 2 \mu \mathrm{m}$.

becomes a line. Number of genital antiaxial setae variable, on one specimen three setae on one side and four on the other.

Anal and adanal plates produce a very interesting situation: plates are fused, but anterior part with line partially delimiting anal and adanal plates; particular microsculpture of aligned points on anal plate, situated parallel, allowing differentiation of plates despite being fused, somewhat similar to
Paulianacarus rugulosus Mahunka, 1995 from Thailand. Genital setae number in P. rugulosus is nine, in P. vietnamese $\mathrm{n}$. sp. asymmetric variations in the number of genital and adanal setae were observed, for example with nine-ten genital setae and fourfive adanal setae. Adanal setae show variation in one specimen: one side with five and another with four. The generic diagnosis of Paulianacarus was made at the same time the author instituted another new 
genus, Millotacarus Balogh, 1960, both from Madagascar. Several authors indicated that the differences between these genera were problematic (Mahunka 1985; Coetzee 2001). Balogh \& Balogh 1987 established the differences between them, adding several characters to the diagnosis of Millotacarus, but this did not solve the problem. The possibility exists that Millotacarus may be a synonym of Paulianacarus. The study of type material is needed.

\section{DISCUSSION}

We compared Bedoslohmannia n. gen. with all genera presenting the following combination of traits: undivided genital plates; fused anal and adanal plates; two pairs of anal and four pairs of adanal setae; broad preanal plates; gastronotic neotrichy and type and shape of legs.

Bedoslohmannia n. gen., showed particular characteristics: shape and disposition of preanal plate; disposition of anal and adanal setae; gastronotic neotrichy; leg shape and chaetotaxy, permitting easy differentiation of the new genus. Setal types, the leg folding process and other important characteristics observed in the new genus were not included in our comparison due to the lack of comparable studies.

The genus appearing most similar to Bedoslohmannia n. gen. is Paulianacarus, for this reason, in the present paper, species from both genera were included.

In Bovicarabodes deharvengi Fernandez, Theron \& Rollard, 2013, B. levyi Fernandez, Theron \& Rollard, 2013 and B. fortdauphini Fernandez, Theron \& Rollard, 2013 (Fernandez et al 2013a) a very interesting "protection mechanism" was described. Several body and leg structures are involved in this process and a series of particular adaptations are observed. Evidently Carabodidae and Lohmannidae present very different characteristics and are evolutionarily distant, but in both cases a protection mechanism exists.

One of the particularities of $B$. anneae n. gen., n. sp. is the "leg-folding process" involving umbrellashaped setae on femora, and the leg housing depressions situated in the lateroventral zone. Processes observed in Bovicarabodes and Bedoslomannia are very different and involve dissimilar structures and strategies.

Grandjean (1950: 101) indicated that the leg housing depression, "Niches latérales pour les pattes" permits receiving of legs when the specimen retracts them against the body. On legs I and II we found three umbrella-shaped setae and on III and IV only one. In both cases, when legs are retracted to their maximum, only apical zone of the longest setae and the solenidia are partially visible. Femoral shape and the number of umbrella-shaped setae vary in legs I-IV, possibly related to the larger number of sensorial organs to protect (in an evolutionary sense).

\section{Acknowledgements}

This work is based on research supported in part by the National Research Foundation of South Africa (UID) 85288. Any opinion, findings and conclusions or recommendations expressed in the material are those of the authors and therefore the NRF does not accept any liability in regard thereto. The authors wish to thank the reviewers for their constructive comments.

\section{REFERENCES}

BALOGH J. 1960. - Oribates (Acari) nouveaux de Madagascar (1 re série). Mémoires de l'Institut scientifique de Madagascar, Série A, vol. 14: 7-37.

BALOGH J. \& BALOGH P. 1987. - A new outline of the Family Lohmanniidae Berlese, 1916 (Acari, Oribatei). Acta Zoologica hungarica 33 (3-4): 327-398.

CoetzeE L. 2001. - New species of the family Lohmanniidae (Acari, Oribatida) from South Africa. Navorsinge van die Nasionale Museum Bloemfontein 17 (3): 57-67.

COINEAU Y. 1974. - Éléments pour une monographie morphologique, écologique et biologique des Caeculidae (Acariens). Mémoires du Muséum national d'Histoire naturelle, 22 Zool., 81: 299.

Deharveng L., Bedos A., Le Cong Kiet, Le Cong MAn \& TruOng Quang Tam 2009. - Endemic arthropods of the Hon Chong hills (Kien Giang), an unrivalled biodiversity heritage in Southeast Asia, in LE Cong Kiet, Truong Quang Tam \& Ly Ngoc Sam (eds), Beleaguered Hills: Managing the Biodiversity of the Remaining Karst Hills of Kien Giang, Vietnam. Nha Xuat Ban Nong Nghiep, TP. Ho Chi Minh: 31-57.

Fernandez N., Theron P. \& Rollard C. 2013a. - The family Carabodidae (Acari: Oribatida) I. Description 
of a new genus, Bovicarabodes with three new species, and the redescription of Hardybodes mirabilis Balogh, 1970. International Journal of Acarology 39 (1): 26-57. http://dx.doi.org/10.1080/01647954.2012.741144

Fernandez N., Theron P. \& Rollard C. 2013b. — Revision of the family Carabodidae (Acari:Oribatida) IV. Aftibodes anjavidilavai gen. nov., sp. nov., Rugocepheus joffrevillei sp. nov., and redefinition of the genus Rugocepheus Mahunka, 2009. International Journal of Acarology 39 (6): 462-480. http://dx.doi. org/10.1080/01647954.2013.822928

Fernandez N., Theron P. \& Rollard C. \& Tied L. 2013c. - Family Carabodidae (Acari: Oribatida) V. The genus Congocepheus Balogh, 1958 (second part), with a redescription of Congocepheus involutus Mahunka, 1997, and descriptions of two new species. Zoosystema 35 (4): 551-579. http://dx.doi.org/10.5252/z2013n4a8

GRANDJEAN F. 1949. - Observation et conservation des très petits Arthropodes. Bulletin du Muséum d'Histoire naturelle 21 (2): 363-370.

Grandjean F. 1950. — Étude sur les Lohmanniidae (Oribates, Acariens). Archives de zoologie expérimentale et générale 87: 95-161.
Krantz G. W. \& Walter D. E. 2009. - A manual of acarology (3rd ed). Texas Tech University Press, Lubbock, $807 \mathrm{p}$.

MAHUNKA S. 1985. - Neue und interessante Milben aus dem Genfer Museum LIV. Oribatids from South India I (Acari: Oribatida). Revue suisse de Zoologie 92 (2): 367-383.

MAHUNKA S. 1995. — New oribatids (Acari:Oribatida) from Thailand. Acta Zoologica Academiae Scientarum Hungaricae 41 (2): 137-145.

MAKOL J. \& GABRYS G. 2005. - Caecothrombium deharvengi sp. nov. (Acari: Actinotrichida Eutrombidiidae) from Vietnam, with a proposal of Caecothrombiinae subfam. nov. Zoologischer Anzeiger, A Journal of Comparative Zoology (4), 243: 227-237.

NorTON R. A. 2010. - Systematic relationships of Lohmanniidae (Acari: Oribatida), in SABELIS M. W. \& Bruin J. (eds), Trends in Acarology. Springer Netherlands: $175-178$.

Norton R. \& BeHAn-Pelletier V. 2009. — Suborder Oribatida, in Krantz G. W. \& Walter D. E. (eds), A manual of acarology (3rd ed). Texas Tech University Press, Lubbock: 430-564.

Submitted on 20 May 2014; accepted on 31 July 2014; published on 26 December 2014. 
